\title{
Dolphin harpooning off the coast of Bahia, Brazil
}

\author{
M. L. V. Barbosa-Filho ${ }^{1 *}$, E. M. Costa-Neto ${ }^{2}$ and D. Danilewicz ${ }^{3,4,5}$
}

\begin{abstract}
Hundreds of thousands of cetaceans die each year due to commercial fishing catches, which is the main threat to global populations of these animals. Mortality by fishing gets disastrous proportions mainly in developing countries, for which effective fisheries management programs, as well as monitoring, environmental education or analysis of the catches impact on cetacean populations are scarce. The aim of this study was to record and describe the intentional catching of dolphins by artisanal fishermen in southern Bahia, Brazil, a region located in the Southwest Atlantic Ocean. In 2012, semi-structured interviews were conducted with 65 commercial fishermen from 13 communities in the region. Catches have been occurring for a long time by the use of harpoons and the pieces of dead animals are used as bait in longline shark fishing, whose fins have a high sale value. Although $81.5 \%(n=53)$ of respondents know the dolphins use, $24.2 \%(n=16)$ reported having used them as bait and only eight (12.1\%) of them admitted to have already killed these marine mammals. It is urgent that these catches are monitored in order to provide baseline information for future conservation actions.
\end{abstract}

Keywords: Cetacean, direct catch, Bait, Harpoon, Conservation, Fishery, Southwestern Atlantic

\section{Introduction}

Interactions between fisheries and marine mammals may be classified as operational, when animals interact directly with fishing gear and operations (e.g. entanglements, bait depredation), or biological, when it occurs on an ecosystemic level (e.g. competition for resources) (Beverton 1985; Northridge \& Hofman 1999). In the former, the distinction between its subcategories is sometimes subtle. For example, if the carcass of a marine mammal is discarded when entangled in the fishing net, or an animal is release from a hook, the process is termed incidental or accidental capture; but when the entangled carcass or the individual is captured by fishermen, the episode is termed non-target catches. Direct catch is a term usually applied when marine mammals are actively hunted or are the commercial target of the fishery (Van Waerebeek \& Reyes 1990; Dolar et al., 1994; Read 2008).

Although small cetacean bycatch is one of the most significant conservation issues affecting this group worldwide

\footnotetext{
* Correspondence: titobiomar@hotmail.com

${ }^{1}$ Programa de Pós Graduação em Zoologia, Rodovia Ilhéus - Itabuna, Universidade Estadual de Santa Cruz - UESC, Salobrinho, CEP: 45662-900 Ilhéus, BA, Brazil

Full list of author information is available at the end of the article
}

(e.g. Read et al. 2006; Reeves et al., 2013), direct catches also have the potential to impact populations. Usually, the animals directly caught are used as bait in the fishery (mostly long-line) or consumed (Mangel et al., 2010; Read 2008; Van Waerebeek et al. 1997). Evidently, since fishermen are aware that it is forbidden the harassment, hunting, or capture of cetaceans in Brazilian waters (Portaria SUDEPE no N-11, 21.Feb.1986), this is a fishery practice very difficult to be assessed and documented by researchers and may be highly underestimated, especially in small-scale fisheries of third-world countries. In Brazil, small cetacean directed catches have been seldom reported. Siciliano (1994) documented that dolphin harpooning and direct catches may be relatively common in Pará, north Brazil, and reported several sites along the Brazilian coast where the blubber of bycaught dolphins were opportunistically used as bait in shark fishery. Di Beneditto et al. (1998) reported the use of dolphin blubber in the large shark fishery off the northern coast of Rio de Janeiro. Recently, the boto Inia geoffrensis (de Blainville 1817) and tucuxi Sotalia fluviatilis (Gervais and Deville 1853) have been directly caught and used as bait in the fishery of piracatinga Calophysus macropterus (Lichtenstein, 1819). 
The direct catches of these cetaceans have emerged in the Amazon river basin as a major conservation problem (Iriarte and Marmontel 2013). Here we report indirect evidences for the practice of dolphin harpooning off the coast of Bahia, northeastern Brazil, revealed by surveys on its fishery communities.

\section{Materials and methods}

Semi-structured interviews with 65 fishermen of 13 communities in the municipalities of Canavieiras $(n=38)$, Una $(n=2)$ and Ilhéus $(n=25)$ were carried out between February and October 2012. This coastline has about 200 kilometers of extension $\left(14^{\circ} 48^{\prime} \mathrm{S}, 39^{\circ} 1^{\prime} \mathrm{W}\right.$ to $15^{\circ}$ $\left.40^{\prime} \mathrm{S}, 38^{\circ} 56^{\prime} \mathrm{W}\right)$ and is inhabited by a human population of approximately 242,000 citizens. The main goal of this interview program was to evaluate the ethnobiological aspects involved in the shark fishery in the region. The questions followed a predefined form, and some of them inquired about the use of cetaceans by fishermen. People interviewed were selected based on the following criteria: (i) to live in the region, (ii) to have at least 15 years of experience in the shark fishery, (iii) to be willing to collaborate with the research. The interviews were initiated after approval of the Ethics in Human Research from the Universidade Estadual de Santa Cruz (Protocol 25275) and ensured the anonymity of the informants.

\section{Results and discussion}

Fishing in Bahia is an activity that has been exploiting a high diversity of teleost fish for centuries (Olavo et al. 2005; Ott 1944). Regional shark catches occur mainly on top of wooden sloops 10-13 meters long equipped with artifacts as longlines and gillnets (locally known as "esperas"). Barbosa-Filho et al. (2014) described these arts of fishing in detail. These boats capture both on the external continental shelf and in the oceanic zone (eight to 70 miles off shore) at 20 to 180 meters deep. In southern Bahia, the increase of the number of boats and the low selectivity of fisheries have greatly affected the stocks and compromised the viability of local fisheries in recent decades (Olavo et al. 2005). Nevertheless, due to the recent regional monetary appreciation of shark fins, there was an increase in the shark fishing efforts and, consequently, on the catches of these fishes.

Based on the information collected on the interviews, small cetaceans captured are regionally used as bait for longline shark fishery. In addition, eight (12.1\%) respondents reported having consumed the meat of these animals. In spite of $81.5 \%(n=53)$ of the fishermen be aware of dolphin use as bait, only $24.2 \%(n=16)$ admitted to have done this practice. However, $56.9 \%(n=37)$ of fishermen interviewed know at least one fisherman who had captured dolphins intentionally and only eight
(12.1\%; all from Canavieiras community) admitted that have already had killed dolphins directly by using harpoon, that are usually ordered and made in regional sawmills. Among these, only three admitted to have harpooned dolphins recently, while others mentioned the practice in the past. However, this is probably an underestimation since to admit a recognized illegal activity during an interview is expected to be uncommon. Some fishermen were uncomfortable to speak about dolphin mortality as they were aware of the Federal Law ( $\left.\mathrm{n}^{\circ} 7.643 / 87\right)$ which prohibits the capture (intentional or not) and harassment of any marine mammal in Brazilian waters. It is unknown when and how the practice of intentionally dolphin capture to use as bait have begun in the region.

The description of the dolphin harpooning is presented below. When a group of dolphins is bowriding the vessel, the largest animal is identified and a handheld harpoon is projected at its dorsal region. Its tip is made of metal and has a wooden pole. The harpoon is tied to a thick cotton line about 400 meters long that is attached to a floatable plastic container. As the harpooned dolphin swim away of the vessel, the line is released. When the distance between the dolphin and the vessel reaches its maximum length, the container is dropped at the sea and is followed by the vessel until the animal stops swimming. When the dolphin is retrieved on board the vessel, it is stabbed and cut with a knife. Its pieces are put in hooks of longline and used as bait for sharks. It was also reported that in some occasions dolphin pieces are tied at gillnets in order to attract sharks. It was not possible to verify the pieces of the captured animals, since fishermen immediately utilized the bubbler and discard the skeleton and viscera motivated by the concern of being charged by official agencies.

Although the description of the target species resembles a small/medium-sized Delphinidae, fishermen were not able to identify it at specific level. They named it "toninha", "golfinho" and/or "boto", lexemes applied by Brazilian fishermen to a wide range of small cetaceans (Souza \& Begossi 2007). The continental shelf where the fishery takes place is inhabited mainly by three small cetacean species: the Guiana dolphin Sotalia guianensis (Van Bénéden 1864), the bottlenose dolphin Tursiops truncatus and the rough-toothed dolphin Steno bredanensis (Lesson 1828). The distribution of oceanic dolphins such as clymene dolphins Stenella clymene and smaller blackfishes (Feresa and Peponocephala) may also overlap with the fishery ground. In this sense, the identity of the species still deserves more investigation.

\section{Conclusions}

This note is the first approach to understand the magnitude of such direct catches on small dolphin populations 
on the coast of Bahia, Brazil. Such catches should be monitored in a long-term in order to provide baseline information for future conservation actions.

\section{Abbreviations}

S, south; W, west

\section{Acknowledgements}

We would like to thank CNPQ for the Master's fellowship granted to M. Barbosa Filho; FAPESBs (APP0028/2011) and Zoology Postgraduate Program (UESC) for logistical support; We would like to thank the biologist Christine Del Vechio Koike for reading and reviewing the manuscript. A special thanks to Salvatore Siciliano for reviewing and giving valuable ideas to improve the manuscript and all fishermen who took part in this study, whether by indicating specialists or providing interviews.

\section{Funding}

The sources of funding of thi study came from the CNPQ by the Master's fellowship (132919/2011-7) granted to M. Barbosa Filho.

\section{Authors' contributions}

MLVBF wrote the entire manuscript, prepared the interview form, and worked in the collection, organization and interpretation of the data. EMCN and DD wrote parts of the manuscript, contributed ideas to the study, and aided in the discussion and review of the manuscript. All the authors read and approved the final manuscript.

\section{Competing interests}

The authors declare that they have no competing interests.

\section{Author details}

'Programa de Pós Graduação em Zoologia, Rodovia Illhéus - Itabuna, Universidade Estadual de Santa Cruz - UESC, Salobrinho, CEP: 45662-900 Ilhéus, BA, Brazil. ${ }^{2}$ Departamento de Ciências Biológicas, Universidade Estadual de Feira de Santana - UEFS, Av. Transnordestina, s/n, Novo Horizonte, CEP: 44036-900 Feira de Santana, BA, Brazil. Instituto Aqualie, Av. Dr. Paulo Japiassu Coelho, 714 - Sala 206, Juiz de Fora, Minas Gerais, Brasil. ${ }^{4}$ Grupo de Estudos de Mamíferos Aquáticos do Rio Grande do Sul, Av. Tramandaí, 976, Imbé, Rio Grande do Sul, Brasil. ${ }^{5}$ Laboratório de Ecologia e Conservação de Mamíferos Marinhos (ECOMMAR), Universidade Estadual de Santa Cruz, Campus Prof. Soane Nazaré de Andrade Rodovia Jorge Amado, km 16 - Salobrinho. Pav. Jorge Amado, Térreo, sala 3007, Ilhéus, Bahia, Brasil.

Received: 15 May 2016 Accepted: 3 June 2016

Published online: 15 July 2016

\section{References}

Barbosa-filho MLV, Schiavetti A, Alarcon DT, Costa-Neto EM. "Shark is the man!": ethno knowledge of Brazil's South Bahia fishermen regarding shark behaviors. J Ethnobiol Ethnomed. 2014;10:54.

Beverton RJH. Analysis of marine mammal - fisheries interaction. In: Beddington $J R$, Beverton RJH, Lavigne DM, editors. Marine Mammals and Fisheries. London: George Allen and Unwin; 1985. p. 3-33.

Di Beneditto APM, Ramos R, Lima NRW. Fishing activity on Northern Rio de Janeiro State (Brazil) and its relation with small cetaceans. Braz Arch Biol Technol. 1998;41:296-302.

Dolar LML, Leatherwood S, Hill CL, Aragones LV. Directed fisheries for cetaceans in the Philippines. International Whaling Commission (Report), United Kingdom. 1994:44:439-50.

Gervais F.L.P. [and Deville]. Sur les mammiféres marins qui fréquentent les côtes de la France et plus particulierement sur une nov elle espéce de dauphins propre a la Méditerranés. Bulletin Sociéte Centrale d'Agriculture et des Comices Agricoles du Département de l'Herault. 1853:40:140-155

Iriarte V, Marmontel M. River dolphin (Inia geoffrensis, Sotalia fluviatilis) mortality events attributed to artisanal fisheries in the Western Brazilian Amazon. Aquat Mamm. 2013;39:116-24

Mangel JC, Alfaro J, Van Waerebeek K, Cáceres C, Bearhop S, Witt MJ, Godley BJ. Small cetacean captures in Peruvian artisanal fisheries: High despite protective legislation. Biol Conserv. 2010;143:136-143.
Northridge SP, Hofman RJ. Marine mammal interactions with fisheries. In: Twiss $J R$, Reeves RR, editors. Conservation and Management of Marine Mammals. Washington: Smithsonian Institution Press; 1999. p. 99-119.

Olavo G, Costa PAS, Martins AS. Caracterização da pesca de linha e dinâmica das frotas linheiras da Bahia, Brasil. In: Costa PAS, Martins AS, Olavo G, editors. Pesca e potenciais de exploração de recursos vivos na região central da Zona Econômica Exclusiva brasileira. Rio de Janeiro: Museu Nacional; 2005. p. 13-34.

Ott CF. Os elementos culturais da pescaria baiana. Boletim do Museu Nacional. 1944:4:1-67.

Read AJ. The looming crisis: interactions between marine mammals and fisheries J Mammal. 2008:3:541-8.

Read AJ, Drinker P, Northridge S. By-catch of marine mammals in U.S. and global fisheries. Conserv Biol. 2006;20:163-9.

Reeves RR, Mcclellan K, Werner TB. Marine mammal bycatch in gillnet and other entangling net fisheries, 1990 to 2011. Endangered Species Research. 2013;20:71-97

Siciliano S. Review of small cetaceans and fishery interactions in coastal waters in Brazil. International Whaling Commission (Report), United Kingdom. 1994;15:241-50.

Souza SP, Begossi A. Whales, dolphins or fishes? The ethnotaxonomy of cetaceans in São Sebastião, Brazil. J Ethnobiol Ethnomed. 2007:3:9.

Van Waerebeek K, Reyes JC. Catch of small cetaceans at Pucusana Port, Central Peru, during 1987. Biol Conserv. 1990:51:15-22.

Van Waerebeek K, Van Bressem MF, Felix F, Alfaro-Shigueto J, Garcia-Godos A, Chavez-Lisambart L, Onton K, Montes D, Bello R. Mortality of dolphins and porpoises in coastal fisheries off Peru and southern Ecuador in 1994. Biol Conserv. 1997:81:43-9.

\section{Submit your next manuscript to BioMed Central and we will help you at every step:}

- We accept pre-submission inquiries

- Our selector tool helps you to find the most relevant journal

- We provide round the clock customer support

- Convenient online submission

- Thorough peer review

- Inclusion in PubMed and all major indexing services

- Maximum visibility for your research

Submit your manuscript at www.biomedcentral.com/submit
) Biomed Central 